\title{
СОЦИАЛЬНО-ДЕМОГРАФИЧЕСКИЙ ПОРТРЕТ СЛУШАТЕЛЯ КОММЕРЧЕСКИХ РАДИОСТАНЦИЙ Г. ИРКУТСКА
}

\begin{abstract}
АНнотАЦия. В статье описаны результаты прикладного исследования слушателей коммерческих радиостанций. В качестве цели исследования выбрано изучение социально-демографического портрета радиослушателя в рамках спектра радиостанций, функционирующих на территории г. Иркутска. Выборочная совокупность сформирована комбинированным способом на основе трехступенчатого отбора с соблюдением квоты отбора респондентов по полу и возрасту в соответствии с половозрастной структурой населения г. Иркутска. Исследование проводилось методом раздаточного анкетирования. По результатам проведенного исследования был представлен портрет типичного радиослушателя с учетом его принадлежности к половозрастной группе, его уровня доходов, образовательного уровня, семейного статуса; интересы, предпочтения слушателей относительно той или иной радиостанции. Выявлены структура, объемы, направленность потребляемой слушателями радиопродукции; уточнены условия и каналы получения слушателями радиопродукции. Произведена оценка слушателями коммерческих радиостанций, вещающих в городской среде Иркутска.
\end{abstract}

кЛючЕВЫЕ словА. Социально-демографическая структура; слушатель радиостанций; радиоаудитория; средства массовой информации.

ИНФОРМАЦИЯ О СТАТЬЕ. Дата поступления 3 мая 2017 г.; дата принятия к печати 19 мая 2017 г.; дата онлайн-размещения 20 июня 2017 г.

S. A. Inkizhinova

Baikal State University, Irkutsk, Russian Federation

\section{SOCIO-DEMOGRAPHIC PROFILE OF LISTENERS OF COMMERCIAL BROADCASTING STATIONS IN IRKUTSK}

ABSTRACT. The article describes the results of an applied research of listeners of commercial broadcasting stations. As the purpose of the study, it selects investigating the socio-demographic profile of the broadcast listener in terms of a variety of broadcasting stations that operate in the territory of Irkutsk. The sample frame is formed by a combined method on the basis of a three-stage selection in compliance with the selection quota for respondents by gender and age in accordance with the age and sex structure of Irkutsk population. The article carries out the study using the method of hands-on questionnaires. The study conducted results in presenting a profile of a typical broadcast listener in view of his or her affiliation with the sex-age group, his or her level of income, the educational level, the family status; the interests and preferences of the listeners to this or that broadcasting station. It reveals the structure, volumes, directivity of the radio products used by the listeners, specifies the terms and channels of receiving the radio products by the listeners. It makes the listeners' assessment of commercial broadcasting stations that broadcast in the urban environment of Irkutsk.

KEYWORDS. Socio-demographic structure; listeners of broadcasting stations; radio audience; the media.

ARTICLE INFO. Received May 3, 2017; accepted May 19, 2017; available online June 20, 2017.

(C) С. А. Инкижинова, 2017

\section{Baikal Research Journal}


Средства массовой информации (СМИ) - это основной источник изменений в окружающей среде, который чутко отслеживает тенденции развития социума. Особое место среди всех существующих средств массовой информации занимает радио. Его преимущество по отношению с другими видам СМИ заключается в том, что радиоволны принимаются портативными устройствами, не требующими привязки к определенному, конкретному месту нахождения. Кроме этого, посредством радио передается вербальная информация, не требующая постоянного зрительного контакта с ее источником. И последнее - радио предоставляет возможность получить наиболее популярные и оперативные типы информации: «новости», «музыка», «спорт», «гороскоп», «погода».

Еще совсем недавно вопрос измерения аудитории радиовещателями не ставился вовсе, поскольку вещателей было немного. Однако, с появлением коммерческих радиостанций и развитием рынка рекламы ситуация стала быстро меняться. Ориентация только на юное поколение, которое предпочитает слушать музыку через разные портативные технические источники, становится неактуальной [1, с. 204]. Меняется социально-демографическая структура населения по различным параметрам, например, по возрасту, по образовательному критерию. Стоит отметить, что поведение потребителей всегда находится под влиянием социальных факторов, основными из которых являются: социальное положение, референтные группы, семья, социальные роли и статусы [2, с. 176]. Как отразил П. Бурдье в своей концепции, «человек при выборе предметов потребления ограничен традициями, моралью, законами своего общества, нормами и ценностями своей референтной группы, а не только экономическими ресурсами» [3].

Для того, чтобы соответствовать интересам и предпочтениям своих радиослушателей, радиостанциям необходима более точная информация об аудитории радиослушателей, их количестве, предпочтениях, социальных характеристиках. Поэтому возникла необходимость в исследовании социального портрета слушателей коммерческих радиостанций г. Иркутска. Данное исследование было проведено в 2015 г., и в дальнейшем планируется продолжение с уточнением задач исследования.

Объектом социологического исследования являлись радиослушатели г. Иркутска, предметом исследования - социально-демографический портрет радиослушателя, его интересы, предпочтения относительно той или иной радиостанции. В качестве цели исследования выбрано изучение социально-демографического портрета радиослушателя в рамках спектра радиостанций, функционирующих на территории г. Иркутска. К задачам исследования отнесены следующие положения:

- определение структуры, объемов, направленности потребляемой слушателями радиопродукции;

- выявление приоритетов радиослушателей в рамках формата радио (персона ди-джея, музыкальный блок, информационный блок, погода и т. д.); уточнение условий и каналов получения слушателями радиопродукции;

- выявление социальных характеристик типичного слушателя коммерческого радио.

Исследование проводилось методом анкетного опроса. Анкетный опрос, относящийся к группе количественных методов сбора информации, обычно используется для изучения массовых явлений, поддающихся измерению, для выявления тенденций, построения прогнозов, определения причинно-следственных связей между переменными [4-6]. Радиоаудитория - массовая социальная категория, которая обладает различными шкальными социально-демографическими показателями, которые можно подвергнуть социологическому измерению [7, с. 105]. Спрос на ту или иную радиостанцию как функцию постоянную также можно

\section{Baikal Research Journal}

электронный научный журнал Байкальского государственного университета 
оценить с помощью формализованного инструментария и измерить частоту наблюдаемых событий, выявить зависимость и влияние переменных данных (объем радиослушателей, наличие конкурентов, наполняемость эфира и т. д.) [8-10].

Выборочная совокупность для данного исследования сформирована комбинированным способом на основе трехступенчатого отбора с соблюдением квоты отбора респондентов по полу и возрасту. Репрезентативность в исследования обеспечивалась поквартирным методом отбора единиц в выборочную совокупность. В первую ступень вошел отбор территорий для проведения опроса. Всего отобрано 18 территорий г. Иркутска, представляющих все административные округа и крупные жилые массивы. Во вторую ступень отбора вошел отбор жилых домов. В районах многоэтажной застройки должны быть отобраны дома разной этажности, разного года постройки. В районах, где имеются и многоэтажные дома, и дома частного индивидуального сектора застройки отобраны жилые и многоквартирные дома, и одно-двухквартирные дома. В третьей ступени происходил отбор собственно респондентов. Отбор респондентов осуществляется с соблюдение квоты отбора по полу и возрасту респондентов. Расчет квот распределения признаков осуществлен на основе статистических данных о половозрастном составе населения г. Иркутска. Был опрошен 501 человек, из них 43,7 \% мужчин и 56,3 \% женщин. Выборка была репрезентативна в соответствии с полом и возрастом. Распределение возрастных групп выборочной совокупности было осуществлено в соответствии с половозрастной структурой населения г. Иркутска ${ }^{1}$.

К трети опрошенных оказались отнесены специалисты или служащие $(30,7 \%)$. Также в выборку примерно поровну попали рабочие (13\%), руководители $(12 \%)$, домохозяйки (13\%), безработные (в том числе учащиеся) $(14 \%)$, пенсионеры $(14 \%)$. Незначительна доля предпринимателей и госслужащих (по 7 \% и $5 \%$ ). Данная структура выборки примерно совпадает с социально-профессиональной структурой населения г. Иркутска.

В табл. 1 представлено распределение ответов на вопрос о предпочтениях респондентов различных радиостанций.

Таблица 1

Распределение ответов на вопрос респондентов о предпочтениях радиостанций

\begin{tabular}{|c|c|c|c|c|}
\hline Радиостанции & $\begin{array}{c}\text { Доля респондентов, } \\
\text { выбравших данную } \\
\text { радиостанцию, \% }\end{array}$ & $\begin{array}{c}\text { Общая численность } \\
\text { респондентов, } \\
\text { выбравших данный } \\
\text { вариант }\end{array}$ & $\begin{array}{c}\text { Количество } \\
\text { респондентов, } \\
\text { выбравших } \\
\text { радио МСМ }\end{array}$ & $\begin{array}{c}\text { Доля респондентов, } \\
\text { выбравших радио } \\
\text { МСМ, к каждой } \\
\text { группе, \% }\end{array}$ \\
\hline Авторадио & 37 & 185 & 36 & 20 \\
\hline Автос & 8 & 37 & 10 & 27 \\
\hline AC ФM & 25 & 5 & - & 0 \\
\hline Вести ФМ & 23 & 115 & 32 & 28 \\
\hline Дача & 18 & 88 & 16 & 18 \\
\hline Европа плюс & 41 & 205 & 80 & 39 \\
\hline Маяк & 13 & 65 & 10 & 15 \\
\hline Радио Радио & 7 & 37 & 10 & 27 \\
\hline Радио России & 17 & 85 & - & 0 \\
\hline Радио Семь & 10 & 49 & 13 & 27 \\
\hline Ретро ФМ & 23 & 115 & 16 & 14 \\
\hline Русское Радио & 32 & 159 & 49 & 43 \\
\hline Шансон & 16 & 81 & 13 & 16 \\
\hline Хит ФМ & 26 & 130 & 46 & 35 \\
\hline $\mathrm{MCM}$ & 29 & 145 & - & - \\
\hline
\end{tabular}

${ }^{1}$ Иркутск в цифрах. 2015. Иркутск : Иркутскстат, 2015. С. 23.

\section{Baikal Research Journal}

электронный научный журнал Байкальского государственного университета 
Из табл. 1 следует, что наибольшая корреляция ответов, связанных с предпочтениями радио МСM, возникла у респондентов, слушающих Русское радио $(43 \%)$, Европа плюс (39\%) и Хит ФМ (35\%). Далее во второй когорте средней корреляции находятся Вести ФМ (28\%), Радио Радио, Радио Семь, Автос (по $27 \%)$. Наименьшая корреляция определяется у Авторадио (20\%), радио Дача $(18 \%)$, Маяк (15\%) и Ретро ФМ (14\%). Респонденты, слушающие такие радиостанции, как АС ФМ, Радио России, не слушают радио МСМ вообще.

Что касается вопроса о месте, где чаще всего респонденты предпочитают слушать радио, то очевидна следующая иерархия вариантов (табл. 2).

Таблица 2

Распределение ответов на вопрос о месте, где предпочитают слушать радио респонденты

\begin{tabular}{|l|r|r|}
\hline \multicolumn{1}{|c|}{ Варианты ответов } & Количество респондентов & Доля опрошенных, \% \\
\hline В автомобиле & 293 & 59 \\
\hline Дома & 191 & 38 \\
\hline На даче & 94 & 19 \\
\hline На занятиях спортом & 34 & 7 \\
\hline Другое & 5 & 1 \\
\hline
\end{tabular}

Из табл. 2 следует, что более половины опрошенных выбрали вариант «в автомобиле» - 59 \%, далее следует вариант «дома» (38 \%), «на даче» - $19 \%$, на занятиях спортом слушают радио $7 \%$ из всех опрошенных респондентов. Вариант «другое» $(1$ \%) включает такие вариации как «на прогулке», «в душе», «в университете».

Распределение ответов на вопрос «Как Вы чаще всего слушаете радио?» представлено в табл. 3.

Распределение ответов на вопрос о способе прослушивания радио

\begin{tabular}{|l|r|r|}
\hline \multicolumn{1}{|c|}{ Варианты ответов } & Количество респондентов & Доля опрошенных, \% \\
\hline С помощью переносного радиоприемника & 120 & 24 \\
\hline С помощью музыкального центра & 78 & 16 \\
\hline С помощью автомагнитолы & 287 & 57 \\
\hline С помощью компьютера (Интернет-ресурса) & 93 & 19 \\
\hline С помощью мобильного телефона & 126 & 25 \\
\hline Другое & 6 & 1 \\
\hline
\end{tabular}

Из табл. 3 следует, что большинство респондентов выбрали вариант «автомагнитолы» $(57 \%)$. В этом случае радиопродукция чаще всего является лишь фоновым условием передвижения на транспорте, а слушатель радио не всегда является радиолюбителем. На втором месте по популярности занимает мобильный телефон $(25 \%)$ и переносной радиоприемник $(24 \%)$. Фактически четверть из всех опрошенных слушают радио через индивидуальный источник радиопродукции, еще одна четверть слушает радио через традиционный радиоприемник. Низкий показатель выбора Интернет-ресурса (19 \% ) респондентов говорит о том, что несмотря на развитие телекоммуникаций, портативные источники радио сохраняют пальму первенства у населения. В комментариях респондентов можно было услышать высказывания типа «слушаю, что ловит мое устройство», "этой радиостанции на моел приемнике нет» и т. д. В качестве варианта «другое» встречаются такие, как «динамик», «проводное радио».

На вопрос о причинах предпочтения того или иного радио респонденты высказались следующим образом (табл. 4). В тройку наиболее значимых причин, из-за

\section{Baikal Research Journal}

электронный научный журнал Байкальского государственного университета 
которых люди слушают радио, входит музыкальная подборка (71 \%), информация о погоде (47 \%), обзор местных новостей (42\%), обзор мировых новостей (41 \%).

Распределение ответов на вопрос о причине прослушивания радио

\begin{tabular}{|l|r|r|}
\hline \multicolumn{1}{|c|}{ Варианты ответов } & Количество респондентов & Доля опрошенных, \% \\
\hline Привлекательная музыкальная подборка & 355 & 71,0 \\
\hline Нравятся ди-джеи & 67 & 13,4 \\
\hline Участие в конкурсах и играх с подарками & 97 & 19,0 \\
\hline Наличие информации о пробках на дорогах & 30 & 6,0 \\
\hline Обзор мировых новостей & 204 & 41,0 \\
\hline Обзор федеральных новостей & 160 & 32,0 \\
\hline Обзор местных новостей & 215 & 42,0 \\
\hline Обзор новостей шоу-бизнеса & - & - \\
\hline Обзор спортивных новостей & 67 & 13,0 \\
\hline Возможность услышать гороскоп & 82 & 16,4 \\
\hline Информация о курсе валюты & 32 & 6,4 \\
\hline Информация о погоде & 235 & 47,0 \\
\hline Актуальное интервью & 50 & 10,0 \\
\hline Возможность услышать точное время & 12 & 12,0 \\
\hline Рейтинг популярных запросов в интернете & 22 & 4,4 \\
\hline Другое & 4 & 4,0 \\
\hline
\end{tabular}

Вариант «другое» связан в основном с индифферентностью слушателя радио при его выборе. Респонденты, не имея конкретной цели прослушивания, радио включают «как фон», «когда больше нечел заняться», при «отсутствии телевизора»; тогда, когда «какое радио ловит, такое и слушаю», «приходится слушать в обшественнол транспорте», «скрашивает скуку», "приходится слушать, то, что слушают коллеги».

На вопрос об общем времени прослушивания радио в течение суток структура ответов сложилась следующим образом (рис. 1).

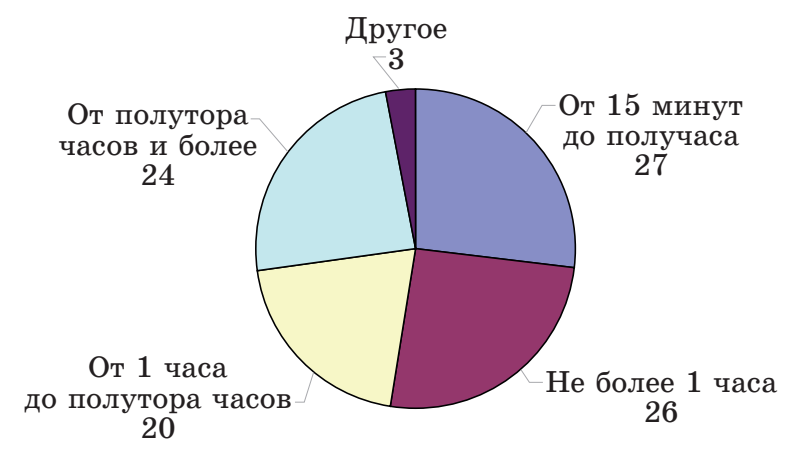

Рис. 1. Распределение ответов на вопрос об общел врелени прослушивания радио, \%

Из рис. 1 следует, что все опрошенные разделились почти поровну на группы по параметру прослушивания радио в день. Почти трети опрошенных (27 \%) удается послушать радио максимум около получаса в день. Еще чуть более четверти (26 \%) всех опрошенных слушают не более часа в сутки. Еще почти четверть из числа всех опрошенных (24 \%) слушают от полутора часов и более, причем при опросе респонденты из этой категории часто имели в виду даже весь день. В варианте «другое» также имеются следующие высказывания: «весь рабочий день», «иногда 15 минут,

\section{Baikal Research Journal}


иногда несколько часов», «на даче может целый день играть, пока не надоест», «по разному», «в дороге и на работе постоянно». В целом, данная небольшая категория равномерно может встроиться в предыдущие четыре сегмента.

Каковы же наиболее распространенные интервалы времени, во время которых городское население слушает радио? Распределение ответов на этот вопрос представлено в табл. 5.

Примерные интервалы, во время которых респонденты

Таблица 5 чаше всего слушают радио

\begin{tabular}{|c|r|r|}
\hline Временные интервалы & Количество респондентов & Доля опрошенных, \% \\
\hline $0-1$ & 12 & 2,4 \\
\hline $1-2$ & 9 & 2,0 \\
\hline $2-3$ & 6 & 1,0 \\
\hline $3-4$ & 7 & 1,4 \\
\hline $4-5$ & 7 & 1,4 \\
\hline $5-6$ & 7 & 1,4 \\
\hline $6-7$ & 31 & 6,0 \\
\hline $7-8$ & 99 & 20,0 \\
\hline $8-9$ & 177 & 35,0 \\
\hline $9-10$ & 133 & 27,0 \\
\hline $10-11$ & 137 & 27,0 \\
\hline $11-12$ & 131 & 26,0 \\
\hline $12-13$ & 153 & 31,0 \\
\hline $13-14$ & 164 & 33,0 \\
\hline $14-15$ & 136 & 27,0 \\
\hline $15-16$ & 125 & 25,0 \\
\hline $16-17$ & 118 & 24,0 \\
\hline $17-18$ & 160 & 32,0 \\
\hline $18-19$ & 163 & 33,0 \\
\hline $19-20$ & 139 & 28,0 \\
\hline $20-21$ & 115 & 23,0 \\
\hline $21-22$ & 65 & 13,0 \\
\hline $22-23$ & 54 & 11,0 \\
\hline $23-24$ & 38 & 8,0 \\
\hline & & \\
\hline
\end{tabular}

Пик активности прослушивания радио населением приходится на время, когда они собираются на работу — от 8 до 9 ч утра (35\%) и от 18 до 19 ч (33\%), когда люди возвращаются с работы домой. В течение дня возрастание интенсивности прослушивания радио происходит в обеденное время (с 13 до 14 ч дня -33 \%). Это объясняется активным использованием респондентами радио в период перемещения из дома на работу и обратно в автомобиле.

Структура респондентов по доходам представлена на рис. 2.

Из рис. 2 следует, что наибольшая доля респондентов $(25 \%)$ отнесла себя к категории, получающих доход от 10000 до 20000 р. Около четверти опрошенных $(26 \%)$ имеют совокупный доход менее 10000 р. Эти явления вполне оправданы, так как почти 40\% опрошенных респондентов относятся к категориям, имеющим достаточно низкий доход (пенсионеры, учащиеся, домохозяйки). Одна пятая часть опрошенных (20 \%) имеет доход, соответствующий среднему размеру зарплаты по г. Иркутск (от 20000 до 30000 р.). 12 \% из числа всех опрошенных имеет доход от 30000 до 40000 р. И только $17 \%$ респондентов отнесли себя к категориям, получающим доход выше $40000 \mathrm{p}$.

\section{Baikal Research Journal}




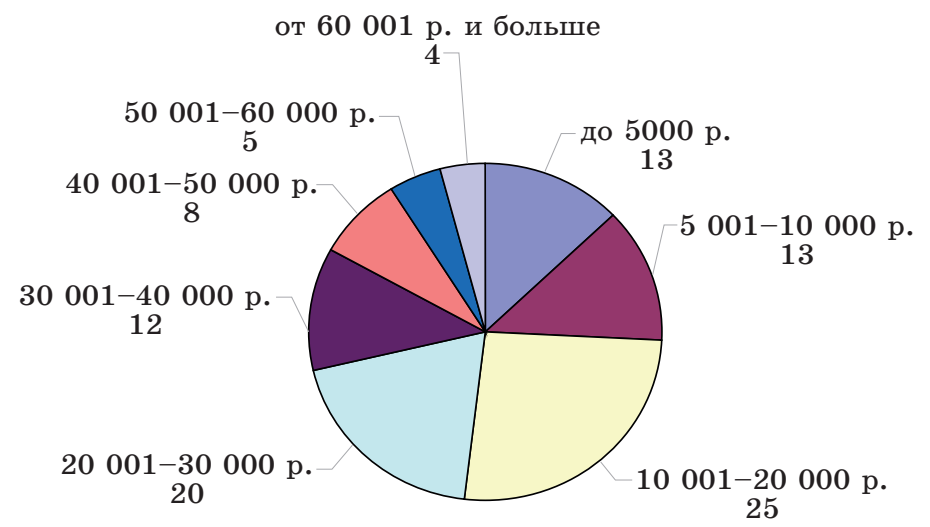

Рис. 2. Распределение респондентов на группы по доходам, \%

Далее в исследовании было обращено внимание на слушателей радиостанции MCM. В табл. 6 представлены связи ответов респондентов, предпочитающих слушать радио МСM, в соответствии с их возрастом.

Связь ответов на вопросы о предпочтениях респондентов

Таблица 6 в каждой возрастной категории

\begin{tabular}{|l|r|r|r|}
\hline Возраст, лет & $\begin{array}{c}\text { Количество } \\
\text { респондентов, всего }\end{array}$ & $\begin{array}{c}\text { Количество опрошенных, } \\
\text { предпочитающих МСM, чел. }\end{array}$ & $\begin{array}{c}\text { Количество опрошенных, } \\
\text { предпочитающих МСM, \% }\end{array}$ \\
\hline $14-17$ лет & 30 & 11 & 37 \\
\hline $18-22$ года & 67 & 16 & 24 \\
\hline $23-30$ лет & 69 & 37 & 54 \\
\hline $31-40$ лет & 113 & 33 & 29 \\
\hline $41-50$ лет & 73 & 10 & 14 \\
\hline 51 и старше & 149 & 38 & 26 \\
\hline Всего & 501 & 145 & 29 \\
\hline
\end{tabular}

Из табл. 6 следует, что из всех возрастных групп более всего радиостанцию MCM предпочитает слушать категория 23-30 лет (54 \%). Более трети респондентов возрастной группы от 14 до 17 лет (37\%) также предпочитает радио МСМ. Наименее значимой возрастной группой для радио МСМ является категория от 41 до 50 лет. Всего 14 \% из них выбрало данное радио.

В табл. 7 представлена структура ответов респондентов в соответствии с уровнем образования, предпочитающих слушать радио МСМ.

Таблица 7

Распределение ответов об образовательном уровне и предпочтениях респондентов

\begin{tabular}{|l|r|r|r|r|}
\hline \multicolumn{1}{|c|}{ Образование } & $\begin{array}{c}\text { Численность } \\
\text { респондентов, } \\
\text { чел. }\end{array}$ & $\begin{array}{l}\text { \% из числа } \\
\text { всех опро- } \\
\text { шенных }\end{array}$ & $\begin{array}{l}\text { Количество респон- } \\
\text { дентов, выбравших } \\
\text { радио МСМ, чел. }\end{array}$ & $\begin{array}{c}\text { Доля респондентов, } \\
\text { выбравших радио } \\
\text { МСМ, \% из числа } \\
\text { данной категории }\end{array}$ \\
\hline Неоконченное среднее & 30 & 6 & 9 & 30 \\
\hline Среднее & 70 & 14 & 16 & 23 \\
\hline Среднее специальное & $\mathbf{1 5 1}$ & 31 & 40 & 27 \\
\hline Высшее & $\mathbf{2 4 4}$ & $\mathbf{5 0}$ & $\mathbf{8 3}$ & $\mathbf{3 4}$ \\
\hline
\end{tabular}

Из табл. 7 следует, что в структуре всех респондентов, предпочитающих радио MCM, наибольшая доля слушателей имеет высшее образование (34 \% из числа

\section{Baikal Research Journal}


опрошенных, имеющих высшее образование). Далее на втором месте больше всего слушают опрошенные с неоконченным среднем образованием (30 \%), далее люди со среднем специальном образованием $(27 \%)$, и со средним образованием $23 \%$ из числа этой возрастной категории.

В табл. 8 представлена связь половой принадлежности респондента и выбора радиостанции МСM.

Таблица 8

Связь ответов на вопрос о предпочтении радио МСМ и пола респондента

\begin{tabular}{|c|r|r|r|rr|}
\hline Пол & $\begin{array}{c}\text { Численность } \\
\text { респондентов, } \\
\text { чел. }\end{array}$ & $\begin{array}{c}\text { \% из числа } \\
\text { всех } \\
\text { опрошенных }\end{array}$ & $\begin{array}{c}\text { Количество респон- } \\
\text { дентов, выбравших } \\
\text { радио МСМ, чел. }\end{array}$ & $\begin{array}{c}\text { Доля респондентов, выбрав- } \\
\text { ших радио МСМ, \% из числа } \\
\text { гендерной группы }\end{array}$ \\
\hline Мужской & 219 & 44 & 52 & 23 \\
\hline Женский & 282 & 56 & 93 & 33 \\
\hline
\end{tabular}

Из табл. 8 следует, что опрошено 44 \% мужчин и 56 \% женщин. Радиостанцию МСМ предпочитают другим радиостанциям $33 \%$ из числа опрошенных женщин и $23 \%$ из всех опрошенных мужчин.

Распределение ответов когорты респондентов, предпочитающих слушать радиостанцию МСM, по уровню дохода представлено в табл. 9.

Связв ответов респондентов, выбравших МСМ, с их доходом

Таблица 9

\begin{tabular}{|c|c|c|}
\hline $\begin{array}{l}\text { Уровень дохода, } \\
\text { p. }\end{array}$ & $\begin{array}{l}\text { Количество респондентов, } \\
\text { выбравших радио МСМ, чел. }\end{array}$ & $\begin{array}{c}\text { Доля респондентов, выбравших радио } \\
\text { МСМ, \% к количеству респондентов дан- } \\
\text { ной категории } \\
\end{array}$ \\
\hline До 5000 & 18 & 28 \\
\hline $\begin{array}{llll}5 & 001-10 & 000\end{array}$ & 12 & 18 \\
\hline $\begin{array}{lllll}10 & 001-20 & 000\end{array}$ & 34 & 26 \\
\hline $20001-30000$ & 30 & 30 \\
\hline $\begin{array}{lllll}30 & 001 & -40 & 000\end{array}$ & 20 & 34 \\
\hline $\begin{array}{lllll}40 & 001 & -50 & 000\end{array}$ & 15 & 37 \\
\hline $\begin{array}{llllll}50 & 001 & -60 & 000\end{array}$ & 11 & 48 \\
\hline От 60001 и выше & 5 & 24 \\
\hline
\end{tabular}

По данным табл. 9 можно сказать, что наибольшая доля слушателей радиостанции МСМ находятся в когортах, имеющих доход от 40000 до 60000 р. Из числа респондентов, имеющих доход от 50000 до 60000 р., слушают МСМ $48 \%$ респондентов; а числа респондентов, имеющих доход от 40000 до 50000 р., слушают МСM $37 \%$ респондентов.

Взаимосвязь оценки отношения к радио МСМ респондентов в зависимости от уровня их дохода представлено в табл. 10.

Данные табл. 10 показывают общую взаимосвязь выставленных оценок респондентами эфира радио МСМ с уровнем их дохода. Очевидна тенденция оценок - она варьируется от «4» (отношусь положительно, слушаю иногда) до «3» (отношусь прохладно, слушаю редко). Более трети из всего числа опрошенных (32\%) поставили эфиру MCM твердую «четверку». Чуть меньше трети (26\%) из всего числа опрошенных поставили данной радиостанции «3». И, наконец, пятая часть респондентов $(20 \%)$ поставила MCM твердую «5». Однако, существует около пятой части $(17 \%)$ респондентов, которые совсем не знают такого радио, и $6 \%$ опрошенных относятся крайне негативно. Разброс негативно настроенных респондентов составляет от 2,5 до 11 \% в разных «доходных» группах, причем большая часть данных респондентов $(11 \%)$ приходится на категорию по доходам от 5000 до 10000 р. По всей вероятности, данная категория - это категория пенсионеров, которым не нравится концепция радио МСM.

\section{Baikal Research Journal}

электронный научный журнал Байкальского государственного университета 
Таблица 10

Распределение ответов на вопрос о доходах и отношении к радиостанции МСМ

\begin{tabular}{|c|c|c|c|c|c|c|c|c|c|}
\hline \multirow{2}{*}{$\begin{array}{c}\text { Оценка эфира } \\
\text { радиостанции } \\
\text { МСМ }\end{array}$} & \multicolumn{9}{|c|}{ Доля респондентов, \% } \\
\hline & $\begin{array}{c}\text { До } \\
5 \stackrel{000}{0}\end{array}$ & $\begin{array}{l}5001- \\
10000\end{array}$ & $\begin{array}{cc}10 & 001- \\
20 & 000\end{array}$ & $\begin{array}{c}20001- \\
30000\end{array}$ & $\begin{array}{ccc}30 & 001- \\
40 & 000\end{array}$ & $\begin{array}{cc}40 & 001- \\
50 & 000\end{array}$ & $\begin{array}{c}50001- \\
60000\end{array}$ & $\begin{array}{c}\text { От } 60001 \\
\text { и выше }\end{array}$ & Всего \\
\hline $\begin{array}{l}5-\text { очень лю- } \\
\text { блю, слушаю } \\
\text { постоянно }\end{array}$ & 19 & 17 & 22 & 28 & 19 & 15 & 17 & - & 20 \\
\hline $\begin{array}{l}4 \text { - отно- } \\
\text { шусь положи- } \\
\text { тельно, слу- } \\
\text { шаю иногда }\end{array}$ & 36 & 26 & 25 & 29 & 40 & 46 & 52 & 19 & 32 \\
\hline $\begin{array}{l}3 \text { - отношусь } \\
\text { прохладно, } \\
\text { слушаю редко }\end{array}$ & 19 & 35 & 25 & 24 & 22 & 22 & 26 & 48 & 26 \\
\hline $\begin{array}{l}2 \text { - не знаю } \\
\text { о существо- } \\
\text { вании такой } \\
\text { станции }\end{array}$ & 20 & 12 & 22 & 14 & 14 & 15 & & 33 & 17 \\
\hline $\begin{array}{l}1 \text { - отношусь } \\
\text { негативно, } \\
\text { раздражает }\end{array}$ & 6 & 11 & 5 & 5 & 5 & 2,5 & 4 & - & 6 \\
\hline Всего & & & & & & & & & 100 \\
\hline
\end{tabular}

Распределение ответов когорты респондентов, предпочитающих слушать радиостанцию MCM, в соответствии с семейным положением представлено в табл. 11.

Таблица 11

Распределение ответов на вопрос о семейном положении респондентов и их предпочтении радио МСМ

\begin{tabular}{|l|r|r|r|}
\hline Варианты ответов & $\begin{array}{c}\text { Количество респондентов, } \\
\text { выбравших радио МСМ, чел. }\end{array}$ & $\begin{array}{c}\text { Доля опрошенных к данной } \\
\text { матримониальной группе, \% }\end{array}$ \\
\hline Холост/не замужем & 62 & 34 \\
\hline Женат/замужем & 62 & 27 \\
\hline Разведен (а) & 19 & 31 \\
\hline Вдовец/вдова & 2 & 8 \\
\hline Всего & 145 & 29 \\
\hline
\end{tabular}

По данным табл. 11 в категориях «женат/замужем», «разведен/разведена», «холост/не замужем» примерно одинаковое количество (около трети опрошенных по каждой категории) слушателей радио предпочитают радио МСМ. Этот показатель равен средней доле опрошенных, предпочитающих данное радио респондентов $(29 \%)$. Это говорит о том, что особых предпочтений радио в зависимости от семейного положения не прослеживается.

В табл. 12 представлено распределение ответов когорты респондентов, предпочитающих слушать радиостанцию MCM, в соответствии с наличием у них детей.

Таблица 12

Распределение ответов на вопрос о наличии детей у респондентов u их предпочтении радио МСМ

\begin{tabular}{|l|r|r|}
\hline \multicolumn{1}{|c|}{ Варианты ответов } & $\begin{array}{c}\text { Количество респондентов, } \\
\text { выбравших радио МСМ, чел. }\end{array}$ & $\begin{array}{c}\text { Доля опрошенных } \\
\text { к данной группе, \% }\end{array}$ \\
\hline Дети есть & 70 & 24 \\
\hline Детей нет & 75 & 36 \\
\hline Всего & 145 & 29 \\
\hline
\end{tabular}

\section{Baikal Research Journal}


По данным табл. 12 явной тенденции по выделению когорты респондентов, предпочитающих радио МСM, по наличию/отсутствию детей нет. Из социальной категории, имеющих детей (294 человека) 70 человек выбрали радио МСМ (24 \%); из категории, не имеющих детей (206 человек), выбрали радио МСМ 75 человек $(36 \%)$. В целом, среднее значение доли респондентов, предпочитающих МСМ из числа всех радиостанций, равно $29 \%$.

Для управления спросом на радиоуслуги аналитикам радиостанций полезно знать конкурентную среду. Для этого респонденты оценили каждую из предложенных радиостанций, вещающих в городской черте Иркутска по пятибалльной системе, где 5 - «очень люблю, слушаю постоянно»; 4 - «отношусь положительно, слушаю иногда»; 3 - «отношусь прохладно, слушаю редко»; $2-$ «не знаю о существовании такой станции»; 1 - «отношусь негативно, раздражает».

Явный фаворит в рейтинге радиостанций - это «Европа Плюс». Более $60 \%$ опрошенных очень любят (оценили на «5») или относятся положительно (оценили на «4») к данной радиостанции. Еще около трети опрошенных относятся прохладно, и $4 \%$ относятся негативно. Это неудивительно: очень сложно охватить все категории радиослушателей и понравиться абсолютно всем.

«Русское радио» по оценкам респондентам занимает второе место. Диаграмма оценок «Русского радио» структурно аналогична диаграмме оценок, поставленных радиостанции «Европа плюс». 58 \% респондентов поставили положительные оценки данной радиостанции (на «4» и «5»), и всего $5 \%$ не слышало о таком радио. Однако достаточно много (31 \%) относятся прохладно и данное радио слушают редко.

Около $40 \%$ респондентов положительно относятся к Авторадио (поставили «4»), и почти пятая часть (22\%) респондентов очень любят и слушают постоянно (оценили на «5»). Не знают о существовании данной радиостанции всего $8 \%$ респондентов.

Радио «Ретро ФМ» 36 \% респондентов ставят твердую «четверку», относятся положительно и слушают иногда. Треть опрошенных (30\%) относятся прохладно и ставят «3». Пятая часть опрошенных очень любят и слушают постоянно. Еще одна популярная радиостанция была оценена респондентами - это «Радио Шансон». Особенностью оценки «Радио Шансон» является достаточно высокий процент респондентов, которых раздражает данное радио $(21 \%)$. Более трети $(31 \%)$ респондентов относятся прохладно (оценили на «3»), и $13 \%$ не знает о существовании подобной радиостанции. Однако, оценивающих данное радио на положительные оценки («4» и «5»), большая часть (53\%). Еще одна радиостанция, которая вещает на территории г. Иркутск это радио Хит ФМ. Данному радио $51 \%$ респондентов выставили положительных оценок. Около трети опрошенных (29 \%) оценило данное радио на «тройку». Объемы сегментов, связанные с оценками «1» и «2», достаточно велики (8\% и $12 \%$ соответственно).

$35 \%$ респондентов оценивают Вести ФМ на «4», еще около трети опрошенных $(29 \%)$ ставят оценку «3» и относятся прохладно, слушают редко. По наблюдениям анкетеров, многие респонденты путают данное радио с другим радио - «Радио России».

«AC-ФМ» радио большинство респондентов (35\%) оценивают на «3». Также около трети опрошенных $(28 \%)$ относятся положительно, и $26 \%$ респондентов не знают о существовании данного радио.

Около 60 \% респондентов слушают «Радио России» редко или иногда, оценивают на «3» или «4». Достаточно странным является тот факт, что $19 \%$ респондентов не знают о существовании данного радио.

\section{Baikal Research Journal}


Почти четверть опрошенных $(24 \%)$ не знают о «Радио Дача», хотя это может быть вполне закономерно. «Радио Дача» вышло в эфир всего несколько лет назад. Аналогично выше названным радиостанциям (Радио России. Вести ФМ) большинство респондентов $(55 \%)$ оценивают радио на «3» и «4».

Около $70 \%$ респондентов оценивают «Радио Маяк» на «тройку» и «четверку». $11 \%$ из числа всех респондентов не знают данной радиостанции, а $9 \%$ респондентов относятся в целом негативно.

Из современных радиостанций выделяется радио «Радио». Данная радиостанция неизвестна почти трети респондентам $(26 \%)$. Из тех, кто знает это радио, треть опрошенных (30 \%) оценивают на «4», слушают иногда и оценивают положительно. Еще примерно около трети опрошенных $(27$ \%) относятся прохладно, слушают редко.

Как и радио «Радио», радио «Семья» неизвестна многим. $21 \%$ респондентов признались, что они незнакомы с подобным радио. Из тех, кто знает данное радио, большинство голосов было отдано оценке «3» $(34 \%)$. Около трети $(28 \%)$ респондентов относятся положительно и ставят оценку « 4 »

Наконец, к радио «МСМ» треть респондентов (31\%) относятся положительно и ставят оценку «4», пятая часть от всего числа опрошенных $(20 \%)$ очень любят радиостанцию и ставят «5»-ку. Однако достаточно высок процент людей, незнакомых с данной радиостанцией $(17 \%)$. Около трети $(26 \%)$ респондентов относятся прохладно и ставят «3».

Таким образом, при сравнении с оценками других радиостанций радио «МСM» пока эффективно конкурирует с радиостанциями «Дача», радио «Радио», «Шансон», «Семья». Вместе с тем радио «MCM» находится в одной когорте с «Хит $\Phi \mathrm{M}$, «АС $\Phi \mathrm{M}$ », «Вести $\Phi \mathrm{M}$ » и уступает пока только «Европе плюс», «Авторадио» и «Русскому радио» .

Итак, в ходе проведенного данного социологического обследования определился социально-демографический портрет слушателя радиостанции коммерческих радиостанций г. Иркутска. В большинстве своем это женщина из возрастной категории 23-30 лет, имеющая высшее образование, холостая, не имеющая детей. Чаще всего она слушает радио в транспорте с помощью автомагнитолы утром по дороге на работу или вечером с работы домой. Вместе с радиостанцией «MCM» она также слушает «Русское радио», «Европу плюс» или «Хит ФМ». В ходе обследования была выявлена закономерность, связанная с доходом опрошенного: при повышении совокупного дохода слушателя постепенно растет интерес к радиостанции «MCM». К основным причинам, по которым респондент слушает радио, относятся привлекательная музыкальная подборка, обзор мировых и местных новостей, а также возможность услышать погоду. В результате анализа конкурентов и сравнения с их оценками было выявлено, что радио «МСМ» имеет более высокие показатели конкурентоспособности, чем у радиостанций «Дача», радио «Радио», «Шансон», «Семья». Показатели известности при сравнении со всеми указанными в данной когорте радиостанциями (за исключением «Шансон») у радио «MCM» выше. Вместе с тем, радио «MCM» имеет схожие показатели с «Хит $\Phi \mathrm{M}$, «АС ФМ» и при эффективном менеджменте может активно конкурировать с ними, пока уступая лишь федеральным радиостанциям «Европе плюс», «Авторадио» и «Русскому радио».

\section{Список использованной литературы}

1. Беркунцова С. А. Радиоаудитория как социологическая категория: углубление понятия, основные характеристики, типологии / С. А. Беркунцова // Austrian Journal of Humanities and Social Sciences. - 2014. - № 7-8. - C. 203-205.

\section{Baikal Research Journal}

электронный научный журнал Байкальского государственного университета 
2. Михальчук А. В. Социальная структура потребления туристских услуг в Хабаровском крае / А. В. Михальчук // Вестник Тихоокеанского государственного университета. - 2016. - № 3. - C. 175-180.

3.Бурдье П. Начала. Choses dites / П. Бурдье. - M. : Socio-Logos Publ., 1994. — 288 c.

4. Жаворонков А. В. Российское общество: потребление, коммуникация и принятие решений, 1967-2004 / А. В. ЖЖаворонков. - М. : Вершина, 2007. - 568 с.

5. Карцева А. А. Влияние сложившейся системы форматов радиовещания на социокультурные характеристики региональной аудитории / А. А. Карцева // Кросс-культурное пространство литературной и массовой коммуникации : материалы Междунар. науч. конф. Майкоп, 21-22 окт. 2016 г. - Майкоп : Изд-во Адыг. гос. ун-та, 2016. C. $240-244$.

6. Кирия И. В. Социальная традиция российской модели коммуникаций / И. В. Кирия // Вестник Московского университета. Сер. 10, ЗЖурналистика. - 2010. - № 1. - С. 51-74.

7. Фомичева И. Д. Социология СМИ / И. Д. Фомичева. - М. : Аспект Пресс, 2007. - 335 c.

8. Копцева О. А. Информационная культура в информационном обществе / О. А. Копцева // Социология и общество: глобальные вызовы и региональное развитие : материалы IV очеред. Всерос. Социол. конгресса. - М. : Рос. о-во социологов, 2012. - С. 853-857.

9. Писаревский В. Г. Социальный портрет аудитории православных интернет-сообществ в социальной сети ВКонтакте / В. Г. Писаревский // Вестник Института социологии. - 2014. - № 3. - С. 130-140.

10. Шариков А. В. Отечественная социология и медиа: ретроспективный взгляд (17652000) / А. В. Шариков, О. Я. Ермолаева // Мониторинг общественного мнения: экономические и социальные перемены. - 2016. - № 4 (134). - С. 98-114.

\section{References}

1. Berkuntsova S. A. Radio audience as a sociological category: deepening concepts, basic characteristics, typology. Austrian Journal of Humanities and Social Sciences, 2014, no. 7-8, pp. 203-205. (In Russian).

2. Mikhal'chuk A. V. Social structure of tourism services in Khabarovsk Territory. Vestnik Tikhookeanskogo gosudarstvennogo universiteta $=$ Bulletin of Pacific National University, 2016, no. 3, pp. 175-180. (In Russian).

3. Bourdieu Pierre. Choses Dites. Paris, Minuit, 1987. 229 p. (Russ. ed.: Bourdieu Pierre. Nachala. Choses dites. Moscow, Socio-Logos Publ., 1994. 288 p.).

4. Zhavoronkov A. V. Rossiiskoe obshchestvo: potreblenie, kommunikatsiya i prinyatie reshenii, 1967-2004 [Russian society: consumption, communication and decision-making, 19672004]. Moscow, Vershina Publ., 2007. 568 p.

5. Kartseva A. A. Impact of existing system of broadcasting formats on socio-cultural characteristics of regional audience. Krosskul'turnoe prostranstvo literaturnoi $i$ massovoi kommunikatsii. Materialy Mezhdunarodnoi nauchnoi konferentsii. Maikop, 21-22 oktyabrya 2016 g. [Cross-Cultural Space of Literary and Mass Communication. Materials of International Scientific Conference. Maikop, October 21-22, 2016]. Maikop, Adyghe State University Publ., 2016, pp. 240-244. (In Russian).

6. Kiriya I. V. Social tradition of Russian model of communications. Vestnik Moskovskogo universiteta. Seriya 10, Zhurnalistika = Bulletin of Moscow University. Series 10, Journalism, 2010, no. 1, pp. 51-74. (In Russian).

7. Fomicheva I. D. Sotsiologiya SMI [Media Sociology]. Moscow, Aspekt Press, 2007. $335 \mathrm{p}$.

8. Koptseva O. A. Information culture in information society. Sotsiologiya i obshchestvo: global'nye vyzovy i regional'noe razvitie. Materialy 4-go Ocherednogo Vserossiiskogo sotsiologicheskogo kongressa [Sociology and society: global challenges and regional development. Materials of Fourth Regular All-Russian Sociological Congress]. Moscow, Russian Sociological Association Publ., 2012, pp. 853-857. (In Russian).

9. Pisarevsky V. G. Social portrait of the audience of orthodox online communities in a social network VKontakte. Vestnik Instituta Sotziologii, 2014, no. 3, pp. 130-140. (In Russian).

\section{Baikal Research Journal}


10. Sharikov A. V., Ermolayeva O. Ya. Russian sociology and media: an retrospective approach. Monitoring obshchestvennogo mneniya: ekonomicheskie $i$ sotsial'nye peremeny $=$ Monitoring of Public Opinion: Economic and Social Changes Journal, 2016, no. 4 (134), pp. 98-114. (In Russian).

\section{Информация об авторе}

Инкижинова Светлана Антоновна - кандидат социологических наук, доцент, кафедра социальной и экономический психологии, социологии и социальной работы, Байкальский государственный университет, 664003, г. Иркутск, ул. Ленина, 11, e-mail: kiciom2014@yandex.ru.

\section{Author}

Svetlana A. Inkizhinova - PhD in Sociology, Associate Professor, Chair of Social and Economic Psychology, Sociology and Social Work, Baikal State University, 11 Lenin St., 664003, Irkutsk, Russian Federation; e-mail: kiciom2014@yandex.ru.

\section{Библиографическое описание статьи}

Инкижинова С. А. Социально-демографический портрет слушателя коммерческих радиостанций г. Иркутска / С. А. Инкижинова // Baikal Research Journal. - 2017. - T. 8, № 2. - DOI: 10.17150/2411-6262.2017.8(2).22.

\section{Reference to article}

Inkizhinova S. A. Socio-demographic profile of listeners of commercial broadcasting stations in Irkutsk. Baikal Research Journal, 2017, vol. 8, no. 2. DOI: 10.17150/24116262.2017.8(2).22. (In Russian).

\section{Baikal Research Journal}

